\title{
Actividad diferencial de fagocitosis e inducción de apoptosis in vitro por serotipos capsulares 5 y 8 de Staphylococcus aureus en neutrófilos de bovinos
}

\author{
Differential phagocytic activity and in vitro induction of \\ apoptosis by Staphylococcus aureus capsular types 5 and \\ 8 in bovine neutrophils
}

\author{
Nancy Montoya Garcíaa, Claudia Giovanna Peñuela Rivasa, Jorge Pablo Acosta Dibarrata, \\ Valente Velázquez Ordoñeza
}

\begin{abstract}
RESUMEN
Se evaluó la actividad de fagocitosis y apoptosis in vitro en leucocitos polimorfonucleares (PMN) de bovinos lecheros frente a Staphylococcus aureus tipos capsulares 5 y 8 . Los neutrófilos se obtuvieron de vacas clínicamente sanas. La actividad de fagocitosis de neutrófilos se determinó a partir de la capacidad e índice de fagocitosis. La evaluación de la apoptosis se realizó por microscopía de campo claro (ML) y de epifluorescencia (MF). Se observaron diferencias entre los tratamientos en ML para la capacidad de fagocitosis, el tipo compacto (CC) fue $86.50 \pm 2.93$, serotipo capsular 5 (CP5) $74.98 \pm 2.44$ y serotipo capsular 8 (CP8) $82.22 \pm 1.5$ ( $P<0.05)$. Los valores para el índice de fagocitosis fueron: CC $6.13 \pm 0.31$, CP5 $4.88 \pm 0.13$ y CP8 $5.22 \pm 0.10$ ( $P<0.05)$. La capacidad de

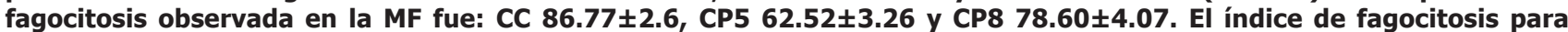
la CC fue de $7.62 \pm 0.55,4.67 \pm 0.29$ para CP5 y de $5.53 \pm 0.40$ para CP8 $(P<0.05)$. Los porcentajes de apoptosis

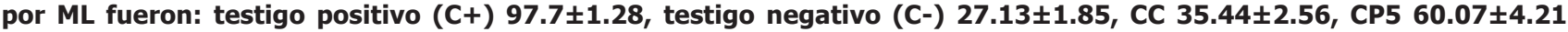
y CP8 45.57 $\pm 4.34(P<0.05)$. En la técnica de MF fueron: $C(+) 95.61 \pm 2.66, C(-) 20.2 \pm 1.77, C C 26.5 \pm 1.65, C P 5$ $52.78 \pm 3.29$ y CP8 $41.33 \pm 2.32(P<0.05)$. Se encontraron diferencias en la capacidad e índice de fagocitosis y apoptosis de los PMN entre los tipos capsulares de S. aureus evaluados. EI CP5 al reducir la actividad de fagocitosis e incrementar la inducción de la apoptosis en los neutrófilos, puede contribuir a la persistencia de la infección intraglandular mamaria del ganado lechero en la mastitis bovina.
\end{abstract}

PALABRAS CLAVE: Fagocitosis, Apoptosis, Neutrófilos, Staphylococcus aureus, Serotipos capsulares.

\begin{abstract}
In vitro phagocytosis and apoptosis activity was evaluated in polymorphonuclear leukocytes (PMN) dairy cattle in the presence of Staphylococcus aureus capsular types 5 and 8. PMN were obtained from clinically healthy cows. The phagocytic activity of neutrophils was assayed through the phagocytic capacity and phagocytic index. Apoptosis was determined by light microscopy (LM) and epifluorescence (FM). Differences were observed between treatments in LM regarding the capacity of phagocytosis; compact type (CC) were $86.50 \pm 2.93$, capsular serotype 5 (CP5) $74.98 \pm 2.44$ and capsular serotype 8 (CP8) $82.22 \pm 1.50(P<0.05)$. The values for the phagocytic index were: CC $6.13 \pm 0.31$, CP5 4.88 \pm 0.13 and CP8 $5.22 \pm 0.10(P<0.05)$. The phagocytic capacity in the FM was: CC 86.77 $\pm 2.6, C P 562.52 \pm 3.26$ and CP8 78.60 \pm 4.07 . The phagocytic index for CC was $7.62 \pm 0.55$, CP5 $4.67 \pm 0.29$ and CP8 $5.53 \pm 0.40(P<0.05)$. The percentages of apoptosis evaluated by LM were: positive control $(C+)$ 97.7 \pm 1.28 , negative control $(C-)$ 27.13 \pm 1.85 , CC $35.44 \pm 2.56$ CP5 $60.07 \pm 4.21$, CP8 45.57 \pm 4.34 and CP5 52.78 \pm 3.29 . In the FM technique were: C $(+)$ 95.61 \pm 2.66 , C(-) 20.2 \pm 1.77 , CC $26.5 \pm 1.65$, CP8 $41.33 \pm 2.32$ respectively $(P<0.05)$. Differences in the in vitro phagocytosis capacity, phagocytic index and apoptosis of PMN were found between the $S$. aureus serotypes tested. Type CP5 decreased phagocytic activity and significantly increased the apoptosis compared with type CP8 in PMN.
\end{abstract}

KEY WORDS: Phagocytosis, Apoptosis, Neutrophils, Staphylococcus aureus, Capsular serotypes.

Recibido el 18 de octubre de 2013. Aceptado el 28 de febrero de 2014.

a Centro de investigación y Estudios Avanzados en Salud Animal, autopista Toluca-Atlacomulco Km 15.5. C.P. 50200. Facultad de Medicina Veterinaria y Zootecnia de la Universidad Autónoma del Estado de México. México. vvo@uaemex.mx. Correspondencia al último autor. 
Nancy Montoya García, et al. / Rev Mex Cienc Pecu 2015;6(1):99-108

El Staphylococcus aureus es el principal patógeno causante de mastitis en las vacas lecheras(1). La persistencia de la infección por $S$. aureus en la glándula mamaria (GM) se asocia a los factores de virulencia que acentúan la inflamación y la respuesta leucocitaria local(2). Un gran número de cepas de $S$. aureus aisladas del ganado lechero con mastitis expresan el exopolisacárido capsular, predominando los serotipos capsulares 5 y 8 considerados los más patógenos(3). Las cepas que no expresan cápsula se denominan cepas compactas (CC). El exopolisacárido capsular del $S$. aureus contribuye a evadir la respuesta inmune innata al afectar la opsonización a través del complemento y la fagocitosis(4).

En la glándula mamaria los leucocitos polimorfonucleares (PMN), constituyen la primera línea de defensa celular frente a la infección a través de la fagocitosis(5). La migración de los PMN en respuesta a los estímulos quimiotácticos del tejido mamario, es crucial en la resistencia y en la resolución del proceso infeccioso(6). Durante la migración vascular y transepitelial en la glándula ocurre su degranulación $(7,8)$ acentuando de manera precoz su apoptosis $(9,10)$. La diapédesis de los PMN disminuye las reservas de glucógeno, reduciendo la fagocitosis y la explosión oxidativa(11). Así mismo la presencia de glóbulos de grasa y las micelas de caseína de leche afectan la actividad de fagocitosis de los PMN(12); incrementándose la apoptosis durante la infección glandular, resultando en la fragmentación del DNA, formación de cuerpos apoptóticos(13), reducción de la capacidad de respuesta a estímulos quimiotácticos y disminución de la intensidad de fagocitosis(14).

Actualmente es poco conocida la influencia del $S$. aureus de los tipos capsulares 5 y 8 sobre la apoptosis de los PMN de vacas lecheras. El objetivo del estudio fue evaluar la actividad de fagocitosis y apoptosis in vitro de los PMN de vacas inducidas por los tipos capsulares 5 y 8 de $S$. aureus.
Staphylococcus aureus is the main causative pathogen of mastitis in dairy cattle(1). The persistence of Staphylococcus aureus infection in the mammary gland (MG) is associated with virulence factors, which exacerbate inflammatory and local leukocyte responses(2). Great number of $S$. aureus strains isolated from dairy cattle with mastitis promote capsular exopolysaccharide expression, predominating types 5 and 8, which are considered the most destructive pathogens( 3 ). The strains that do not express capsule are called compact strains (CC). S. aureus capsular exopolysaccharide contributes to evade the innate immune response and opsonization is affected through the alteration of complement activity and phagocytosis(4).

In the mammary gland, the polymorphonuclear leukocytes (PMN) constitute the first line of defense against invading microorganisms and eliminate pathogens by a process called phagocytosis(5). The migration of PMNs in response to chemotactile stimuli of the mammary tissue is crucial in the resistance and in the resolution of the infectious process(6). During migration through blood vessels and through interstitial tissue, degranulation occurs in the mammary gland $(7,8)$, accentuating early activation of apoptosis $(9,10)$. PMN diapedesis reduces glycogen stores, by minimizing phagocytosis and oxidative burst(11). Likewise, presence of fat globules and milk casein micella affect the phagocytic activity of PMNs(12), accentuating apoptosis during the mammary gland infection, resulting in DNA fragmentation and therefore apoptotic body formation(13), reduced response to chemotactile stimuli and decreased phagocytic function(14).

Currently, the effect of $S$. aureus capsular types 5 and 8 on PMN apoptosis in dairy cattle is little known. The objective of the study was to evaluate the phagocytic activity and in vitro PMN apoptosis in cows induced by $S$. aureus capsular types 5 and 8 .

The PMN animal donor group included three multiparous dairy cows, clinically healthy with a 
grupo de animales donadores de PMN se integró con tres vacas lecheras multíparas, clínicamente sanas con un periodo pos partum promedio de 121 días. Los criterios de inclusión de las vacas fueron: serología negativa a anticuerpos anti $S$. aureus tipo capsular 5 y $8(15)$, un conteo de células somáticas en leche $<200 \times 10^{3}$ células/ml(16) y bacteriológicamente negativas a $S$. aureus en tres muestreos consecutivos(17). El cuidado de las vacas se realizó siguiendo los lineamientos de las Normas Oficiales Mexicanas NOM 056-ZOO-1999 y NOM 062-ZOO-1999, bajo la supervisión del comité de bioética institucional de la Facultad de Medicina Veterinaria y Zootecnia de la Universidad Autónoma del Estado de México. Para evaluar la capacidad de fagocitosis (CFN) e índice de fagocitosis (IFN) se emplearon dos grupos experimentales y un grupo testigo denominados: CP5, PMN + cepa de $S$. aureus tipo capsular 5; CP8, PMN + cepas capsulares 8 y de testigo (CC), PMN + cepa compacta. Se emplearon para evaluar la inducción de la apoptosis un grupo testigo positivo $\mathrm{C}(+)$ integrado por PMN incubados con ciclofosfamida $(400 \mu \mathrm{g} / 100 \mu \mathrm{l})$ y un grupo testigo negativo C(-) con PMN suspendidos en medio de cultivo. Los ensayos in vitro se realizaron por triplicado.

Para evaluar el índice de fagocitosis, capacidad de fagocitosis y apoptosis, se utilizaron dos cepas de $S$. aureus de origen bovino para cada tratamiento; caracterizadas con los antisueros anti-cap5 y anti-cap8, por medio de PCR se identificaron los genes cap5 y cap8 mediante los procedimientos descritos por Verdier et a(18). Como testigos se emplearon las cepas de S. aureus: ATCC 12598 (Cowan1) tipo compacto, la cepa ATCC 25904 de tipo capsular 5(19) y la cepa ATCC 49525 tipo capsular 8(20).

Los PMN se aislaron de sangre obtenida por venopunción de la vena yugular; en tubos de recolección al vacío (Vacutainer, Becton Dickinson, USA), con solución de ácido cítrico dextrosa $1: 9(21)$. El conteo total y diferencial de leucocitos se realizó empleando un hemocitómetro y la tinción del frotis sanguíneo postpartum period of $121 \mathrm{~d}$. The inclusion criteria for the cows were the following: negative serology for anti-type 5 and 8 antibodies(15), somatic cell count in milk $<200 \times 10^{3}$ cells/ $\mathrm{ml}(16)$ and bacteriologically negative for $S$. aureus in three consecutive samplings(17). Cows were taken care of according to the guidelines of the Normas Oficiales Mexicanas NOM 056ZOO-1999 and NOM 062-ZOO-1999, under the supervision of the Comité de Bioética Institucional of the Facultad de Medicina Veterinaria y Zootecnia of the Universidad Autónoma del Estado de México. For the evaluation of phagocytic capacity (CFN) and phagocytic index (IFN), two experimental groups and one control group were used: CP5, PMN + S. aureus capsular type 5 strain; CP8, PMN + capsular 8 strain and control (CC), PMN + compact strain. For the evaluation of apoptosis induction, a positive control group $\mathrm{C}(+)$ composed of PMN incubated with cyclophosphamide $(400 \mu \mathrm{g} / 100 \mu \mathrm{l})$ and a negative control group C(-) with PMN suspended in culture medium were used. The in vitro assays were carried out in triplicate.

For the evaluation of phagocytic index, phagocytic capacity and apoptosis, two $S$. aureus strains from bovine origin were used for each treatment. Characterized with anti-cap5 and anticap8 antisera, the cap5 and cap8 genes were identified by PCR using the procedures described by Verdier et a(18). The following $S$. aureus strains were used as controls: ATCC 12598 (Cowan1) compact-type, ATCC 25904 capsular type 5(19) and ATCC 49525 capsular type 8(20).

PMNs were isolated from blood obtained by direct venipuncture of the jugular vein using vacutainers (Vacutainer, Becton Dickinson, USA) with acid-citrate-dextrose solution 1:9. Total white blood cell counts and differential white blood cell counts were carried out using a hemocytometer and Giemsa-stained blood smears. PMNs were isolated by hypotonic lysis of erythrocytes (22). The purity of mature PMNs was observed in May-Grünwald-Giemsa-stained blood smears. Cell viability was determined using 
con Giemsa. Los PMN se aislaron por el método de la lisis hipotónica de eritrocitos(22). La pureza de PMN maduros se observó en un frotis celular sanguíneo teñido con May Grunwald-Giemsa. La viabilidad se determinó por el método de exclusión de azul de tripán al 4\%(23). La pureza y viabilidad de los PMN fueron estimadas al $95 \%$.

Para determinar la actividad de fagocitosis in vitro se empleó como sustrato una suspensión de $S$. aureus 2 x $10^{8} \mathrm{UFC} / \mathrm{ml}$ inactivada a $120^{\circ} \mathrm{C}$ durante 20 min y conservada a $4{ }^{\circ} \mathrm{C}$ hasta su uso; se realizó una proporción neutrófilo:bacteria de 1:10(24). En un microtubo se adicionaron: 0.1 $\mathrm{ml}$ de la suspensión bacteriana, $0.1 \mathrm{ml}$ de suero autólogo inactivado a $56{ }^{\circ} \mathrm{C}$ y $0.8 \mathrm{ml}$ de suspensión de neutrófilos, incubado a $37^{\circ} \mathrm{C}$ durante una hora. Posteriormente a cada tratamiento se le adicionó lisostafina $(1 \mu \mathrm{g} / \mathrm{ml}$, Iysostaphin SIGMA, USA), reincubándose por 30 min. Se realizó un frotis teñido con May Grunwald-Giemsa previo a la observación en microscopía de campo claro (ML) 100x.

La actividad de fagocitosis se evaluó mediante el índice de fagocitosis (número promedio de bacterias fagocitadas por PMN), al observar $y$ contar 200 células en diferentes campos microscópicos. La CFN se estimó a partir del porcentaje de PMN que fagocitaron, contando 200 células. En la evaluación mediante microscopía de epifluorescencia (MF) para estimar el IFN y CFN, se empleó una suspensión inactivada de $S$. aureus 2 × $10^{8} \mathrm{UFC} / \mathrm{ml}$, conjugada con isotiocianato de fluoresceína. La evaluación de la apoptosis in vitro de los neutrófilos, se realizó a partir de un frotis teñido con May Grunwald-Giemsa(25), observado en ML 100x, enumerando 200 PMN en varios campos de acuerdo a las características morfológicas(26). La observación de la apoptosis se realizó bajo el microscopio de epifluorescencia con bromuro de etidio $100 \mu \mathrm{g} / \mathrm{ml}$ (PROMEGA, Madison USA) y naranja de acridina $100 \mu \mathrm{g} / \mathrm{ml}$ (SIGMA-AIDRICH, USA); a $100 \mu$ de la muestra de estudio se adicionaron $8 \mu$ le las soluciones de contraste fluorescente(27). the trypan blue exclusion test at $4 \%(23)$. Purity and viability of PMNs were estimated at $95 \%$.

For determination of in vitro phagocytic activity, a suspension of $S$. aureus $2 \times 10^{8} \mathrm{CFU} / \mathrm{ml}$, inactivated at $120{ }^{\circ} \mathrm{C}$ for $20 \mathrm{~min}$ and stored at 4 ${ }^{\circ} \mathrm{C}$ until used, was used as substrate, with a neutrophil:bacterium ratio of $1: 10(24)$. A microtube was filled with the following: $0.1 \mathrm{ml}$ of bacterial suspension; $0.1 \mathrm{ml}$ of autologue serum, inactivated at $56{ }^{\circ} \mathrm{C}$ and $0.8 \mathrm{ml}$ of neutrophil suspension, incubated at $37^{\circ} \mathrm{C}$ for one hour. Subsequently, lysostaphin was added to each treatment $(1 \mu \mathrm{g} / \mathrm{ml}$, lysostaphin SIGMA, USA), incubating again for $30 \mathrm{~min}$. A May-GrünwaldGiemsa-stained smear was made prior to observation by light field microscopy (LM) 100X.

The phagocytic activity was evaluated by means of the phagocytic index (average number of phagocytized bacteria by $\mathrm{PMN}$ ), by observing and counting 200 cells in different microscope fields. CFN was estimated from the percentage of phagocytizing PMN, counting 200 cells. In the evaluation by epi-fluorescence microscopy (FM), for estimating IFN and CFN, an inactivated suspension of $S$. aureus $2 \times 10^{8} \mathrm{UFC} / \mathrm{ml}$, conjugated with fluorescein isothiocyanate, was used. In vitro evaluation of neutrophil apoptosis was performed using a May-Grünwald-Giemsastained smear(25), observed by LM 100X, enumerating 200 PMNs in different fields, according to the morphological characteristics(26). The observation of apoptosis was performed under the epi-fluorescence microscope using $100 \mu \mathrm{g} /$ $\mathrm{ml}$ ethidium bromide (PROMEGA, Madison, USA) and $100 \mu \mathrm{g} / \mathrm{ml}$ acridine orange (SIGMA-AIDRICH, USA); $8 \mu$ of fluorescent contrast solutions were added to $100 \mu$ l of the study sample(27).

The analysis of the results was conducted on the basis of IFN and CFN of the treatments, compared with the control group. The mean and the standard deviation were determined. An analysis of variance was performed for the evaluation of phagocytic activity and apoptosis induction differences between treatments and the control group(28), the comparison of 
Cuadro 1. Actividad de fagocitosis in vitro de neutrófilos de vacas lecheras (Media \pm desviación estándar) Table 1. In vitro phagocytic activity of neutrophils in dairy cattle (Mean \pm standard deviation)

\begin{tabular}{lccccccc}
\hline & \multicolumn{3}{c}{ Phagocytic index (IFN) } & & \multicolumn{3}{c}{ Phagocytic capacity (CFN) } \\
\cline { 2 - 4 } Microscopy & CC & CP5 & CP8 & & CC & CP5 & CP8 \\
\hline Light field & $6.13 \pm 0.31$ & $4.88 \pm 0.13$ & $5.22 \pm 0.10$ & & $86.50 \pm 2.93$ & $74.98 \pm 2.44$ & $82.22 \pm 1.50$ \\
Epifluorescence & $7.62 \pm 0.55$ & $4.67 \pm 0.29$ & $5.53 \pm 0.40$ & & $86.77 \pm 2.6$ & $62.52 \pm 3.26$ & $78.60 \pm 4.07$ \\
\hline
\end{tabular}

$\mathrm{CC}=S$. aureus compact-type strain; $\mathrm{CP} 5=S$. aureus capsular type strain $5 ; \mathrm{CP} 8=S$. aureus capsular type 8 . IFN and CFN were significantly different between treatments and with regard to the control group $(P<0.05)$.

El análisis de los resultados se realizó a partir del IFN y CFN de los tratamientos, comparados con el grupo testigo. Se determinó la media y la desviación estándar. Para evaluar las diferencias de la actividad de fagocitosis e inducción de apoptosis entre los tratamientos y el grupo testigo se realizó un análisis de varianza(28), la comparación de medias de los tratamientos se realizó con la prueba de Tukey, utilizando el programa GraphPad Prism 5.01 (GraphPad Sofware Inc. USA).

En el estudio de fagocitosis in vitro en los PMN de bovinos lecheros, se observaron diferencias en la actividad de fagocitosis y en la inducción de apoptosis entre los tratamientos con cepas capsulares de $S$. aureus. treatment means was carried out with Tukey's test, using GraphPad Prism 5.01 (GraphPad Software Inc. USA).

There were differences in phagocytic activity and induction of apoptosis between treatments with $S$. aureus capsular strains. The values obtained in the in vitro assay for evaluating phagocytic activity of PMNs, observed by LM for CFN, were: compact strain (CC), $86.50 \pm$ 2.93; CP5, $74.98 \pm 2.44$ and CP8, $82.2 \pm 1.50$. In the observation by FM, CNF for the compacttype was $86.77 \pm 2.60$; for $\mathrm{CP} 5,62.52 \pm 3.26$ and for CP8, $78.60 \pm 4.07(P<0.05)$ (Table 1).

The IFN observed by LM in the different treatments was: $\mathrm{CC}, 6.13 \pm 0.3 ; \mathrm{CP} 5,4.88 \pm$

Figura 1. Neutrófilos sanguíneos de bovinos mostrando apoptosis: A) condensación del núcleo, B) fragmentación nuclear, C) formación de cuerpos apoptóticos

Figure 1. Bovine blood neutrophils showing apoptosis: A) condensation of the nucleus, B) nuclear fragmentation, C) apoptotic body formation

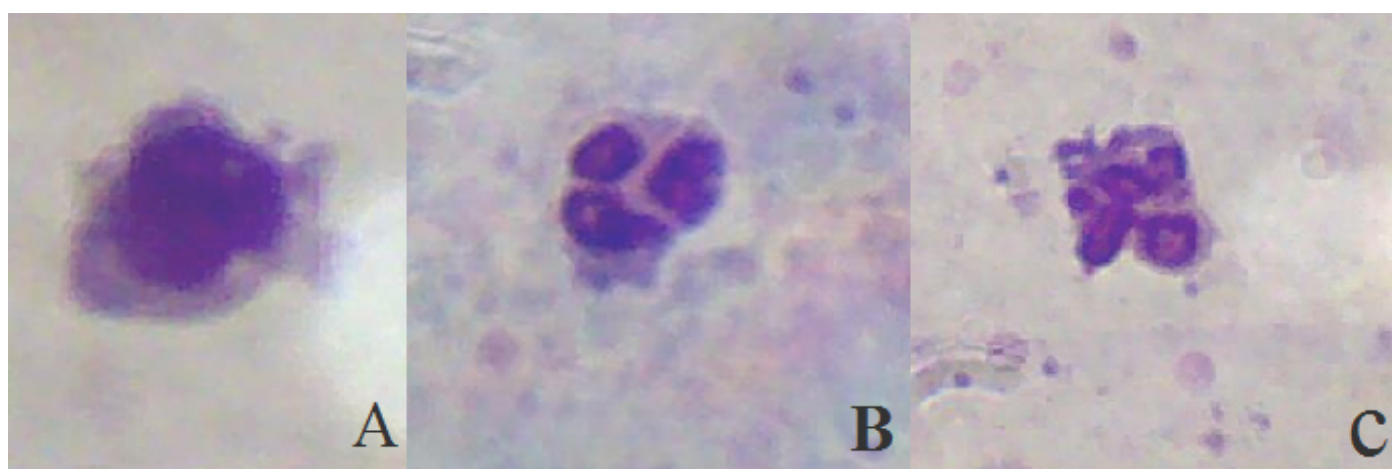

Light field microscopy100X, May-Grünwald-Giemsa. 
Los valores obtenidos en el ensayo in vitro para evaluar la actividad de fagocitosis de los PMN observada mediante ML para la CFN fueron: cepa compacta (CC) $86.50 \pm 2.93$, CP5 $74.98 \pm 2.44$ y CP8 $82.2 \pm 1.50$. En la observación con MF la CFN para el tipo compacto fue $86.77 \pm 2.60$, para CP5 $62.52 \pm 3.26$ y CP8 $78.60 \pm 4.07 \quad(P<0.05)$ (Cuadro 1$)$.

El IFN observado mediante ML en los diferentes tratamientos fueron, para CC $6.13 \pm 0.3, \mathrm{CP} 5$ $4.88 \pm 0.13$ y CP8 $5.22 \pm 0.1(P<0.05)$. En la observación con MF los valores para el IFN fueron: CC $7.62 \pm 0.55$, CP5 $4.67 \pm 0.29$ y CP8 $5.53 \pm 0.4(P<0.05)$ (Cuadro 1). Al evaluar los métodos de observación microscópica para el IFN estos mostraron diferencias entre los tratamientos con respecto al grupo testigo $(P<0.05)$.

La inducción de la apoptosis por los tipos capsulares de $S$. aureus, se evaluó mediante las características morfológicas del núcleo y el

Figura 2. Proporción de neutrófilos bovinos apoptóticos inducidos por $S$. aureus después de una hora de incubación, observados por microscopía de campo claro (LM) y microscopía de fluorescencia (FM)

Figure 2. Proportion of apoptotic bovine neutrophils induced by $S$. aureus after an hour of incubation, observed by light field microscopy (LM) and fluorescence microscopy (FM)

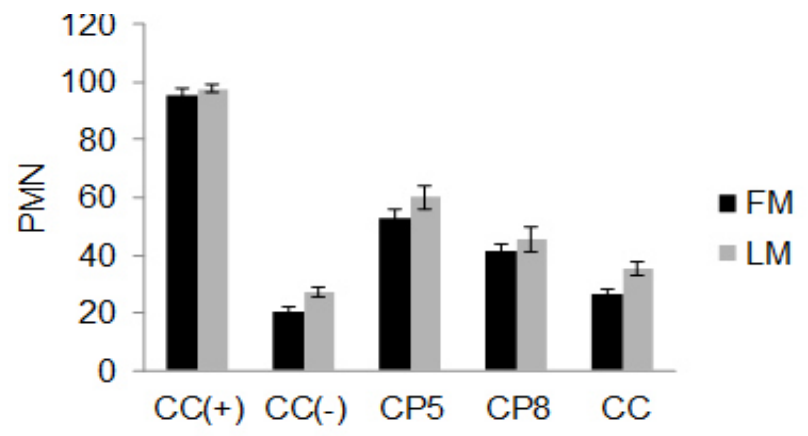

Positive control $\mathrm{CC}(+)$; negative control $\mathrm{CC}(-)$ neutrophils; CP5 type 5 capsule strain; CP type 8 capsule strain and CC compact strain. Significant differences among treatments $(P<0.05)$.
0.13 and $\mathrm{CP} 8,5.22 \pm 0.1(P<0.05)$. In the observation by $\mathrm{FM}$, the values for IFN were: CC, $7.62 \pm 0.55$; CP5, $4.67 \pm 0.29$ and CP8, $5.53 \pm 0.4 \quad(P<0.05)$. The evaluation of the microscopy observation methods showed differences between treatments with respect to the control group $(P<0.05)$.

The induction of apoptosis by $S$. aureus capsular types was evaluated by morphological characteristics of the nucleus and cytoplasm observed in May-Grünwald-Giemsa-stained smears (Figure 1).

Figure 2 depicts the apoptosis percentages between groups: $\mathrm{CC}(+), 97.7 \pm 1.28 ; \mathrm{CC}(-)$, $27.13 \pm 1.85 ;$ CC, $35.44 \pm 2.56$; CP5, $60.07 \pm$ 4.21 and CP8, $45.57 \pm 4.34(P<0.05)$.

In FM, wet smears stained with ethidium bromide and acridine orange showed viable green coloured cells and orange coloured apoptotic cells. The apoptotic cells showed zeiosis, nuclear fragmentation and some showed apoptotic body formation (Figure 3 ). With this technology, the values of apoptosis induction were: $\mathrm{CC}(+), 95.61 \pm 2.66$; $\mathrm{CC}(-), 20.2 \pm 1.77$;

Figura 3. PMN obtenidos de sangre bovina, teñidos con bromuro de etidio y naranja de acridina. Cuerpos apoptóticos $(A)$ y célula viable $(B)$

Figure 3. PMN obtained from bovine blood. Ethidium bromide and acridine orange staining. Apoptotic bodies (A) and viable cell (B)

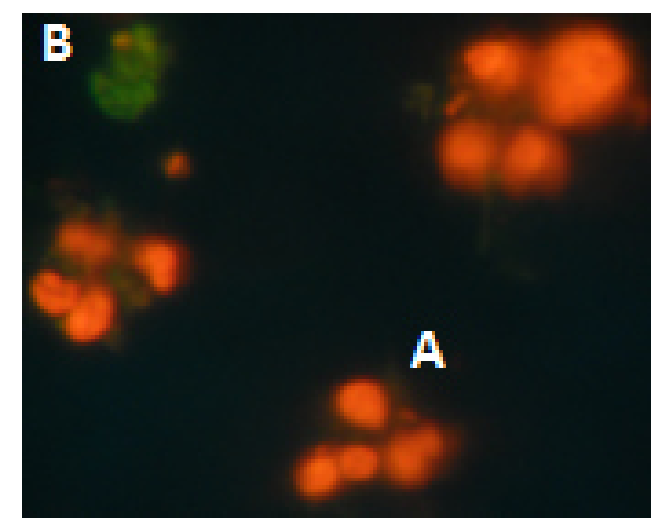

Epi-fluorescence microscopy 100X. 
citoplasma apreciadas en los frotis teñidos con May Grunwald-Giemsa (Figura 1).

En la Figura 2 se observan los porcentajes de apoptosis entre los grupos: $\mathrm{CC}(+) 97.7 \pm 1.28$, $\mathrm{CC}(-) 27.13 \pm 1.85, \mathrm{CC} 35.44 \pm 2.56, \mathrm{CP} 5$ $60.07 \pm 4.21$ y $\mathrm{CP} 845.57 \pm 4.34(P<0.05)$.

En MF en los frotis húmedos teñidos con bromuro de etidio y naranja de acridina se observaron células viables de color verde y apoptóticas de color anaranjado. Las células apoptóticas presentaron zeiosis, fragmentación nuclear y en algunas se apreció la formación de cuerpos apoptóticos (Figura 3). Mediante esta técnica los valores de inducción de apoptosis fueron, $\mathrm{CC}(+) 95.61 \pm 2.66, \mathrm{CC}(-)$ $20.2 \pm 1.77$, CC $26.5 \pm 1.65$, CP5 52.78 \pm 3.29 y CP8 $41.33 \pm 2.32$ respectivamente $(P<0.05)$. En las técnicas de ML y MF se observaron diferencias entre los tratamientos con respecto al grupo testigo $(P<0.05)$.

Mediante los ensayos in vitro con PMN obtenidos de sangre de vacas fue posible evaluar la actividad de fagocitosis e inducción de apoptosis ante la presencia de $S$. aureus CP5 y CP8. Los PMN aislados de sangre por el método de lisis hipotónica de vacas lecheras en periodo medio de lactación mostraron alta viabilidad y pureza, permitiendo realizar los ensayos. Coincidiendo con los estudios de Van Oostveldt et a(29) quienes observaron que las vacas de este periodo de lactación tienen una menor proporción de PMN apoptóticos de manera normal, que las vacas en lactación temprana.

Por la técnica de ML y de MF se determinó la viabilidad de los PMN en el ensayo in vitro y la presencia de las células y los cambios relacionados con la apoptosis temprana y tardía. En el grupo testigo $\mathrm{C}(+)$ se observaron células apoptóticas identificadas por presentar zeiosis, cariopicnosis, fragmentación nuclear y formación de cuerpos apoptóticos(30). En los grupos experimentales CP5 y CP8 se identificaron PMN que presentaban características morfológicas de células apoptóticas en mayor proporción que el
CC, $26.5 \pm 1.65 ;$ CP5, $52.78 \pm 3.29$ and CP8, $41.33 \pm 2.32$, respectively $(P<0.05)$. In $L M$ and FM techniques, there were differences between treatments with respect to the control group $(P<0.05)$.

By means of in vitro assays with PMNs obtained from bovine blood, it was possible to evaluate phagocytic activity and induction of apoptosis in presence of $S$. aureus CP5 and CP8. The PMNs isolated by the hypotonic lysis method of blood obtained from dairy cows during mid lactation period, showed high viability and purity, allowing to perform the assays. This coincided with the studies conducted by Van Oostveldt et $a(29)$, who observed that cows during this lactation period normally had a lower rate of apoptotic PMNs, in comparison with cows during early lactation period.

PMN viability in the in vitro assay and the presence of cells and changes associated with early and late apoptosis were determined by LM and FM technique. In the control group $(\mathrm{C}+)$, apoptotic cells were identified by showing zeiosis, kariopicnosis, nuclear fragmentation and apoptotic body formation(30). In CP5 and CP8 experimental groups, PMNs showed greater proportion of apoptotic cells than group C(-) and CC. The differences observed between CP5 and CP8 treatments are important for explaining the development of $S$. aureus infection, by showing that CP5 induces greater levels of apoptosis in PMNs of dairy cattle. The differences observed between phagocytic activity and apoptosis induction in bovine PMNs caused by CP5 and CP8, may also be associated with deficient opsonization in presence of antibodies and complement in milk during infection $(31,32)$.

The present study demonstrated that $S$. aureus CP5 induced greater percentage of apoptosis in PMNs, in comparison with CP8 in dairy cattle. According to Kampen et al(33), the noncapsulated $S$. aureus strains stimulate respiratory burst activity in bovine PMNs, while the capsulated strains poorly stimulate the activity. A very important step in respiratory burst is 
Nancy Montoya García, et al. / Rev Mex Cienc Pecu 2015;6(1):99-108

grupo C(-) y CC. Las diferencias observadas entre los tratamientos CP5 y CP8 son importantes para explicar el desarrollo de la infección por $S$. aureus, al mostrar que CP5 induce una mayor apoptosis en los PMN de las vacas lecheras. Las diferencias observadas entre la actividad de fagocitosis e inducción de apoptosis en los PMN bovinos ocasionada por CP5 y CP8 puede estar asociada también a la deficiente opsonización en presencia de anticuerpos y complemento en la leche al ocurrir la infección $(31,32)$.

En el estudio se demostró que CP5 de $S$. aureus indujo un porcentaje mayor de apoptosis en los PMN en comparación con el CP8 en las vacas lecheras. De acuerdo a lo reportado por Kampen et a/(33), las cepas no capsuladas de S. aureus estimulan la actividad del estallido respiratorio en PMN bovinos, mientras que las cepas capsuladas estimulan pobremente la actividad. Un paso importante en el estallido respiratorio es la activación de la NADPH oxidasa. Algunos autores refieren que la activación de la NADPH oxidasa y la generación de oxidantes en el fagosoma del PMN humano y murino frente a $S$. aureus, previene la activación de la cascada de caspasas citoplasmáticas que induce la apoptosis por vía intracelular o extracelular(34). Asimismo Watts et al(35) observaron que las cepas de $S$. aureus CP5 a diferencia de las CP8 tienen mayor sobrevivencia en neutrófilos obtenidos de sangre de ratón.

En PMN los cambios típicos de la apoptosis se presentan a las $24 \mathrm{~h}$ después de la estimulación con un análogo sintético del péptido de muramil dentro del tejido mamario en las vacas jóvenes. Así mismo, después de $24 \mathrm{~h}$ de la administración de una solución PBS y lipopolisacáridos administrados en la glándula mamaria, se observaron alteraciones típicas de la apoptosis en los PMN, aunque el pico más alto se produjo a las $48 \mathrm{~h}$ postratamiento(36). En el presente trabajo los cambios típicos se presentaron a partir de una hora de incubación in vitro. Nilsdotter-Augustinsson et a( $(37)$, consideran una
NADPH oxidase activity. Some authors report that NADPH oxidase activity and generation of oxidants in human and murine PMN phagosomes in presence of $S$. aureus, prevents the activation of caspase cascade, (interacting with cytoplasmic factors) that induces apoptosis by intracellular or extracellular stimuli(34). Likewise, Watts et al(35) observed that $S$. aureus CP5 strains, in contrast with CP8, have higher survival rates in neutrophils obtained from mouse blood.

In PMN, typical changes of apoptosis are observed $24 \mathrm{~h}$ after stimulation by a synthetic muramyl peptide analogue within the mammalian tissue in young cows. Likewise, $24 \mathrm{~h}$ after the administration of PBS solution and lipopolysaccharides in the mammary gland, typical alterations of PMN apoptosis were observed, although the highest peak was generated at $48 \mathrm{~h}$ after treatment(36). In the present study, typical changes were observed one hour after in vitro incubation. NilsdotterAugustinsson et al(37) considered that modulation of PMN apoptosis isolated from human blood, is an important characteristic of $S$. aureus virulence and suggest that capsular $S$. aureus strains can modulate apoptosis in bovine PMN and that serotype CP5 increases this process in higher percentage than CP8.

The results obtained in this study confirm that the capsule is a virulence factor of $S$. aureus, which has an effect on phagocytic activity by reducing IFN and inducing the apoptosis process in dairy cattle PMNs. CP5 induced a higher degree of apoptosis, in comparison with CP8 and compact, which could be associated with the persistence of intraglandular mammalian infection in dairy cattle during the development of mastitis.

\section{ACKNOWLEDGEMENTS}

Special thanks to CONACyT for the scholarship 326195 awarded for postgraduate studies (PCARN-UAEM), To PROMEP-SEP for funding 
característica importante de la virulencia del $S$. aureus la modulación de la apoptosis en PMN aislados de sangre humana, y sugiere que $S$. aureus capsular puede modular la apoptosis en PMN bovinos y que el serotipo CP5 incrementa este proceso en mayor porcentaje que CP8.

Los resultados obtenidos en este estudio confirman que la cápsula es un factor de virulencia del $S$. aureus que afecta la actividad de fagocitosis, al reducir el IFN e inducir el proceso de apoptosis en los PMN de bovinos lecheros. La CP5 indujo un mayor grado de apoptosis, en comparación con los CP8 y compacto, lo cual podría estar relacionado con la persistencia de la infección intraglandular mamaria en el ganado lechero durante el desarrollo de la mastitis.

Los resultados obtenidos en este estudio confirman que la cápsula es un factor de virulencia del $S$. aureus que afecta la actividad de fagocitosis, al reducir el IFN e inducir el proceso de apoptosis en los PMN de bovinos lecheros.

\section{AGRADECIMIENTOS}

Al CONACYT por la beca 326195 para cursar estudios de Posgrado (PCARN-UAEM). Al PROMEP- SEP por el financiamiento otorgado al proyecto "Caracterización genotípica de Staphylococcus aureus de tipo capsular en aislamientos obtenidos de hatos lecheros de producción familiar del valle de Toluca" y a la Secretaría de Investigación de la UAEM en el proyecto "Variación genético de aislamientos de $S$. aureus MRSA obtenidos de vacas lecheras en unidades de producción familiar, clave 3484/ 2013CHT .

\section{LITERATURA CITADA}

1. Castañeda $V H$, Jäger $S$, Wolter $W$, Zschöck $M$, Castañeda UMA, El-Sayed A. Isolation and identification of main mastitis project "Genotypic characterization of capsular Staphylococcus aureus in isolates obtained from family owned dairy farms in the Toluca valley", To the Secretaría de Investigación of the UAEM in project "Genetic variation of $S$. aureus MRSA isolates obtained from dairy cattle in family production units", key number 348/2013CHT.

End of english version

pathogens in Mexico. Arq Braz Med Vet Zootez 2013;64(2):377-382.

2. Sutra $L$, Poutrel B. Virulence factors involved in the pathogenesis of bovine intramammary infections due to Staphylococcus aureus. J Med Microbiol 1994;40:79-89.

3. Tollersrud T, Kenny K, Reitz AJ, Lee JC. Genetic and serologic evaluation of capsule production by bovine mammary isolates of Staphylococcus aureus and other Staphylococcus spp. from Europe and the United States. J Clin Microbiol 2000;38(8):2998-3003.

4. O'Riordan K, Lee JC. Staphylococcus aureus Capsular Polysaccharides. Clin Microbiol Rev 2004;17(1):218-234.

5. Rinaldi M, Moroni P, Leino L, Laihia J, Paape MJ, Bannerman DD. Effect of cis-urocanic acid on bovine neutrophil generation of reactive oxygen species. J Dairy Sci 2006;89(11):4188-4201.

6. Bannerman DD, Paape MJ, Lee JW, Zhao X, Hope JC, Rainard P. Escherichia coli and Staphylococcus aureus Elicit Differential Innate Immune Responses following Intramammary Infection. Clin Diagn Lab Immunol 2004; 11:463-472.

7. Rysanek D, Sediva I, Sladek Z, Babak V. Intramammary infections of mammary glands in unbred heifers: absolute and differential somatic cell counts. Veterinarni Medicina 1999;44:199-203.

8. Paape MJ, Bannerman DD, Zhao X, Lee J. The bovine neutrophil: Structure and function in blood and milk. Vet Res 2003;34:597-627.

9. Van Oostveldt K, Paape JM, Burvenich C. Apoptosis of bovine neutrophils following diapedesis through a monolayer of endothelial and mammary epithelial cells. J Dairy Sci 2002; 85:139-147.

10. Rysanek D, Sladek Z, Vasicková D, Faldyna M. Effects of certain inducers of leukocytes migration into the bovine mammary gland on neutrophil apoptosis manifestation in a subsequent in vitro cultivation. Physiol Res 2005;54:305312.

11. Smits E, Burvenich C, Guidry AJ, Heyneman R, MassartLeën $A$. Diapedesis across mammary epithelium reduces phagocytic and oxidative burst of bovine neutrophils. Vet Immunol Immunopathol 1999;68(2-4):169-76.

12. Reinitz DM, Paape MJ, Mather IH. Effect of phagocytosed fat and casein on the intraphagosomal $\mathrm{pH}$ in bovine polymorphonuclear leukocytes. Proc Soc Exp Biol Med 1982;170:281-285. 
Nancy Montoya García, et al. / Rev Mex Cienc Pecu 2015;6(1):99-108

13. Schulze-Osthoff K, Ferrari D, Los M, Wesselborg S, Peter ME. Apoptosis signaling by death receptors. Eur J Biochem 1998;254:439-59.

14. Sladek Z, Rysanek D, Ryznarova H, Faldyna M. Neutrophil apoptosis during experimentally induced Staphylococcus aureus mastitis. Vet Res 2005;36:629-643.

15. Karakawa WW, Fournier JM, Vann WF, Arbeit R, Schneerson RS, Robbins JB. Method for the serological typing of the capsular polysaccharides of Staphylococcus aureus. J Clin Microbiol 1985;22(3):445-447.

16. Echeverri JJZ, Jaramillo MG, Restrepo LFB. Evaluación comparativa de dos metodologías de diagnóstico de mastitis en un hato lechero del Departamento de Antioquia. Rev Lasallista Investig 2010;7:49-57.

17. Capuco AV, Paape MJ, Nickerson SC. In vitro study of polymorphonuclear leukocyte damage to mammary tissue of lactating cows. Am J Vet Res 1986;47:663-668.

18. Verdier I, Durand G, Bes M, Taylor KL, Lina G, Vandenesch $F$, Fattom AI, Etienne J. Identification of the capsular polysaccharides in Staphylococcus aureus clinical isolates by PCR and agglutination tests. J Clin Microbiol 2007;45(3):725-729.

19. Cocchiaro JL, Gomez MI, Risley A, Solinga R, Sordelli DO, Lee JC. Molecular characterization of the capsule locus from non-typeable Staphylococcus aureus. Mol Microbiol 2006;59(3):948-960.

20. Fattom AI, Sarwar J, Basham L, Ennifar S, Naso R. Antigenic determinants of Staphylococcus aureus type 5 and type 8 capsular polysaccharide vaccines. Infect Immune 1998;66(10):4588-4592.

21. Worku M, Paape MJ, Marquardt WW. Modulation of Fc receptors for IgG on bovine polymorphonuclear neutrophils by interferon gamma though de novo RNA transcription and protein synthesis. Am J Vet Res 1994;55:234-238.

22. Velázquez V, Pescador N, Gorodezky C, Saltijera J. In vitro differencial neutrophil phagocytosis activity on Staphylococcus aureus when obtained from blood and milk of dairy cows in early lactation period. Rev Latinoam Microbiol 2008;50(3,4):66-71.

23. Salgar SK, Papee MJ, Alston-Mills B, Miller RH. Flow cytometric study of oxidative burts activity in bovine neutrophils. Am J Vet Res 1991;52(8):1201-1207.

24. Sutra L, Mendiola C, Rainard P, Poutrel B. Encapsulation of Staphylococcus aureus Isolates from mastitic milk: Relationship between capsular polysaccharide types 5 and 8 and colony morphology in serum-soft agar, clumping factor, Teichoic acid, and Protein A. J Clin Microbiol 1990;28(3):447451.

25. Sladek Z, Rysanek D, Faldyna M. Light microscopic and flow cytometric detection of apoptosis and necrosis of neutrophils in the mammary gland of the virgin heifer. Acta Vet Brno 2001;70:149-155.

26. Sladek Z, Rysanek D. Morphology of apoptosis of polymorphonuclear leukocytes isolated from mammary glands of unbred heifers. Vet Med Czech 2000;45(3):7181.

27. McGahon AJ, Mstin SJ, Bissonnette RP, Mahboubi A, Shi $Y$, Mogil RJ, Nishioka WK, Green DR. The end of the (Cell) line: Methods for the study of apoptosis in vitro. Methods Cell Biol 1995;46:153-85.

28. Lee JW, O'Brien CN, Guidry AJ, Paape MJ, Shafer-Weaver $\mathrm{KA}$, Zhao X. Effect of a trivalent vaccine against Staphylococcus aureus mastitis lymphocyte subpopulations, antibody production, and neutrophil phagocytosis. Canad J Vet Res 2005;69:11-18.

29. Van Oostveldt K, Vangroenweghe F, Dosogne H, Burvenich F. Apoptosis and necrosis of blood and milk polymorphonuclear leukocytes in early and midlactating healthy cows. Vet Res 2001;32:617-622.

30. Taatjes DJ, Sobel BE, Budd RC. Morphological and cytochemical determination of cell death by apoptosis. Histochem Cell Biol 2008;129:33-43.

31. Cunnion KM, Lee JC, Frank MM. Capsule production and growth phase influence binding of complement to Staphylococcus aureus. Infect Immun 2001;69(11):67966803.

32. Cunnion KM, Zhang HM, Frank MM. Availability of complement bound to Staphylococcus aureus to interact with membrane complement receptors influences efficiency of phagocytosis. Infect Immun 2003;71(2):656-662.

33. Kampen HA, Tollersrud T, Lund A. Staphylococcus aureus capsular polysaccharide types 5 and 8 reduce killing by bovine neutrophils in vitro. Infect Immun 2005;73(3):15781583.

34. Wilkie RP, Vissers MCM, Dragunow M, Hampton MB. A Functional NADPH oxidase prevents caspase involvement in the clearance of phagocytic neutrophils. Infect Immun 2007;75(7):3256-3263.

35. Watts A, Ke D, Wang Q, Pillay A, Nicholson-Weller A, Lee JC. Staphylococcus aureus strains that express serotype 5 or serotype 8 capsular polysaccharides differ in virulence. Infect Immun 2005;73(6):3502-3511.

36. Sládek Z, Rysánek D. Apoptosis of polymorphonuclear leukocytes of the juvenile bovine mammary gland during induced influx. Vet Res 2000;1:553-563.

37. Nilsdotter-Augustinsson A, Wilsson A, Larsson J, Stendahl O, Ohman L, Lundqvist-Gustafsson H. Staphylococcus aureus, but not Staphylococcus epidermidis, modulates the oxidative response and induces apoptosis in human neutrophils. APMIS 2004;112:109-18. 